\title{
Potential Currency Areas in East Asia using United States, Japan or China as the Monetary Anchor
}

\author{
Chee-Heong Quah* \\ Fecha de recepción: 3 de febrero de 2012; fecha de aceptación: 8 de marzo de 2013.
}

Abstract: This paper applies fuzzy clustering techniques to developed and emerging economies in East Asia, in order to arrive at an identification of potential subgroups of economies for monetary union. The statistical criteria employed is the one suggested by the Optimal Currency Areas theory, and the period examined includes the recent global crisis. Three alternative monetary anchor countries are proposed, namely the United States, Japan and China, and hence, to an extent, the analysis does indicate the relative importance of the three world's largest economies to East Asia. Due to the endogeneity of the convergence criteria in the eurozone, founding member states of EMU are used as a point of reference for East Asia to indicate the level of preparedness for monetary union in this region. Findings indicate that Singapore and Hong Kong are relatively prepared for integration. In addition, results do also signify the dominance of Japan despite the prevalence of the dollar standard in the region.

Keywords: Asia, US, Japan, China, Europe, monetary union, dollar, business cycle.

\section{Zonas de integración potenciales en el este de Asia utilizando a Estados Unidos, Japón o China como el ancla monetaria}

Resumen: Este documento aplica técnicas de fuzzy clustering para economías desarrolladas y emergentes del este de Asia, con objeto de llegar a identificar subgrupos de economías que tengan potencial para una unión monetaria. Los criterios estadísticos empleados son los que sugiere la teoría de Áreas Monetarias Óptimas, y el periodo examinado incluye la crisis global reciente. Se proponen, como ancla monetaria, tres países alternativos que son Estados Unidos, Japón y China, y así, hasta cierto punto, el análisis hace una clara indicación de la relativa importancia de las tres mayores economías del mundo para el este asiático. Debido a la endogeneidad del criterio de convergencia en la eurozona, se usan los países miembros que fundaron la Unión Monetaria Europea como punto de referencia para el este asiático; ello, para indicar el nivel de preparación del este de Asia para una unión

*Chee-Heong Quah, quahch@um.edu.my, senior lecturer, Faculty of Business and Accountancy, University of Malaya. Kuala Lumpur, Malaysia. Special thanks to Prof. Michael Artis, from the University of Manchester, and to Prof. Patrick Crowley, from Texas A\&M University - Corpus Christi, for their help and guidance on the subject. 
monetaria. Los hallazgos indican que Singapore y Hong Kong están relativamente preparados para la integración. Además, los resultados también muestran el dominio de Japón, a pesar de que el dólar prevalece como estándar en la región.

Palabras clave: Asia, Estados Unidos, Japón, China, Europa, unión monetaria, dólar, ciclo de negocios.

JEL classification: C19, E32, F10, F15, F41, O53.

\section{Introduction}

R ecent competitive devaluations undertaken by world economies in $\mathcal{~}$ wake of the global recession vividly demonstrate the perils of flexible exchange rates. ${ }^{1}$ In light of this and other "beggar-thy-neighbor" protectionist policies pursued by these sovereign countries to improve their trade balances, changes in nominal exchange rates would be of little benefit and may even be harmful when every country embarks on similar policies -ultimately domestics price and wage levels would have to adjust to regain competitiveness-. Against this backdrop, it might have been better to implement fixed exchange rates for the sake of greater stability in exchange rates and consistency in national policies, which can be interpreted as one kind of international coordination.

In East Asia, on October 25, 2009 at the Southeast Asian summit, Yukio Hatoyama, former prime minister of Japan suggested a common currency for the region while former Australian Prime Minister, Kevin Rudd proposed a pan-Pacific economic community that would include the United States. A breakthrough in monetary cooperation in the region had actually taken place earlier in 2007 in the ASEAN $+3^{2}$ meeting in which the Chiang Mai Initiative - a network of bilateral swap agreements which allows member countries to borrow funds from one another- was initiated and implemented in stages since. At the same time the proposal of the Asian Currency Unit (ACU) was also put forward.

In the literature, Bayoumi and Eichengreen (1994), Goto and Hamada (1994), and Kawai and Takagi (2005) have once concluded that East Asia came as close as Western Europe to being a currency area. On the con-

${ }^{1}$ For a discussion on exchange rate issues and policies during the recent global crisis in East Asia, see Witte (2010) and Choi, Kim and Sung (2010).

${ }^{2}$ Association of Southeast Asian Nations (ASEAN) was founded in 1967 and had five members initially (Indonesia, Malaysia, the Philippines, Singapore, and Thailand). Today, it contains five more members (Brunei, Myanmar, Cambodia, Laos and Vietnam). 'ASEAN + 3 ' is ASEAN plus Japan, Korea, and China. 
trary, some authors such as Wilson and Choy (2007) have demonstrated that East Asian countries are structurally too different to constitute a monetary union. Nevertheless, these studies do commonly suggest that some countries are more ready than the others for cooperation on the monetary side.

While shock symmetry analysis as demonstrated by the above studies is useful and appealing, cross-country homogeneity in other dimensions of convergence is equally important too. In light of this, in Quah and Crowley (2010), using "hard" clustering analysis and US dollar as the proposed monetary anchor the authors managed to identify symmetrical subgroups of countries in East Asia in respect of dimensions related to the optimum currency areas (OCA) theory. In a nutshell, the OCA criteria could signify the appropriateness or readiness of a country for fixing the exchange rate. In other words, cluster analysis enables one to recognize groups of countries with symmetrical degrees of readiness for exchange rate fixation.

Whilst retaining the ocA-related facets as the main analytical tool, this paper adds to the earlier study in the following ways. First, instead of the "hard" clustering method, this paper uses techniques of "fuzzy" clustering to ascertain homogenous groups of countries in which for each country the "degree of belongingness" to each of the homogenous groupings is determined. Fuzzy clustering takes into account the possibility that a country may be similar to one country or group of countries in some respects and at the same time share certain other characteristics with another country or group of countries. To the best knowledge of the author, this methodology has been scarcely applied in this area. Second, instead of setting only the United States as the monetary anchor country for East Asia, given the recent global crisis and developments in the international economic landscape, the present study also proposes the alternative anchor countries of Japan and China. In some ways, the analysis will signify the relative dominance of these three world's largest economies to the region. Third, we also include the European Economic and Monetary Union (EMU) founding members as cases of reference in the exercise whereby East Asian countries which are found associated with the euro members and hence share similar features with them are interpreted as comparatively prepared for monetary union. ${ }^{3}$

\footnotetext{
${ }^{3}$ Constrained by data availability, the East Asian economies examined here are Japan, Korea, China, Taiwan, Hong Kong, the Philippines, Thailand, Malaysia, Singapore and Indonesia where Japan and China are also used alternatively as reference countries besides United States. The EMU countries involved are Germany, Austria, Belgium, Finland, France, Ireland,
} 
The rest of the paper proceeds as follows. In the first section we discuss the methodology of fuzzy clustering, clarifying the associated statistics of the analysis. Then, in section II, we turn to discuss the ocA criteria and the representation we give them in this study. In section III we present and discuss the results obtained in applying methods of fuzzy clustering to variables reflecting those criteria. Section IV recapitulates the key findings and concludes.

\section{Methodology}

In this paper, cluster analysis is proposed to examine the similarities and dissimilarities of economic structure in the data and to uncover homogenous subgroups of countries. Broadly there are two variants of cluster analysis, hard and fuzzy clustering. While hard clustering approach (e.g. Quah and Crowley, 2010) attempts to assign each object to one and only one cluster or group, fuzzy clustering method (Artis and Zhang, 2002; Boreiko, 2003; Nguyen, 2007; Tsangarides and Qureshi, 2008) allows some ambiguity in the data by assigning each object to a cluster with a membership coefficient indicating the degree of belongingness of the object to that cluster. In a sense, it has more power in approximating the situation involving incomplete and uncertain information, which is often the case in the real world. An object (country) is most likely belonged to the cluster with which it has the highest membership coefficient. Practically, it provides a country's policymakers the most-fitting potential partner country or grouping of partner countries, the second most-fitting ones, and so on for integration purposes. Cluster analysis is different from other techniques such as cointegration, VAR, or OCA index in the sense that cluster analysis is capable of drawing out homogeneous groupings of countries given a set of criteria. Moreover, time-series modeling techniques by and large only examine a very limited number of dimensions at a time, such as symmetry in real exchange rate movements and/or symmetry in responses to shocks, assuming that these dimensions also reflect other facets of convergence. Further reasons of using this technique as opposed to other conventional techniques are briefed in Appendix B.

The algorithm of fuzzy analysis used in the analysis is the widely used fuzzy C-means (FCM) technique proposed by Dunn (1973) and Bezdek

Italy, Luxembourg, the Netherlands, Portugal and Spain, where Germany acts as the reference country for these euro founding countries. 
(1973) (see Anderberg, 1993; Kaufman and Rousseeuw, 1990 for more details). The algorithm is briefly explained here. In the terminology of cluster analysis, there are $n$ objects (countries) and $p$ variables (criteria) in a dataset with each object being denoted by a vector $x_{i}\left(x_{i}=\left(x_{i 1}, x_{i 2,}, \ldots, x_{i p}\right)\right.$ for $i=1,2, \ldots, n)$. Each variable is standardized with mean and standard deviation being equal to zero and unity respectively so that the variables are treated as having equal importance in determining the partition structure.

The dissimilarity coefficient or distance $d_{i j}$, between two objects $x_{i}$ and $x_{j}$ is defined by the Euclidean distance:

$$
d_{i j}=\sqrt{\sum_{k=1}^{p}\left(x_{i k}-x_{j k}\right)^{2}}
$$

The fuzzy C-means technique is based on the minimization of the following objective function:

$$
\sum_{k=1}^{m} \frac{\sum_{i=1}^{n} \sum_{j=1}^{n} u_{i k}^{2} u_{j k}^{2} d_{i j}^{2}}{2 \sum_{j=1}^{n} u_{j k}^{2}}
$$

subject to the following constraints:

$$
u_{i k} \geq 0, \sum_{k=1}^{m} u_{i k}=1 \text { for } i=1,2, \ldots, n ; k=1,2, \ldots m
$$

in which $u_{i k}$ stands for the membership coefficients of object $x_{i}$ belonging to cluster $k$ and $m$ is the number of clusters. In fuzzy clustering, the membership coefficients of each object are non-negative with their sum over all clusters being equal to one. On the contrary, in hard clustering membership coefficients are effectively forced to take the value of either one or zero.

The above algorithm is based on the assumption that the number of clusters is known in advance. In practice, researchers have to determine the number of clusters to ensure that the clusters are as "crisp" (or clearcut) as possible. Hence, to determine the optimal number of clusters Xie and Beni's (1991) index (XBI) is used here: 


$$
\mathrm{XBI}=\frac{1}{n} \frac{\sum_{i=1}^{n} \sum_{k=1}^{m}\left(u_{i k}\right)^{2} d_{i k}^{2}}{\min _{i, k} d_{i k}^{2}}
$$

where $d_{i k}$ is the Euclidean distance between $x_{i}$ and the center of the cluster $k, \sum_{i=1}^{n} u_{i k}^{2} x_{i} / \sum_{i=1}^{n} u_{i k}^{2}$. Recent application of this validation index with FCM includes Nguyen (2007). Low indexes indicate less (greater) variations within (between) clusters. Hence, smaller index values represent more compact and separated clusters. ${ }^{4}$

Other than that, it is also useful to introduce one diagnostic statistic in fuzzy analysis, Dunn's Partition Coefficient (DPC) which measures the degree of fuzziness in the partitions. DPC is defined as the sum of squares of all the membership coefficients divided by the number of objects and may be further normalized as in the following formula:

$$
\mathrm{DPC}=\frac{m \sum_{i=1}^{n} \sum_{k=1}^{m} \frac{u_{i k}^{2}}{n}-1}{m-1}
$$

The normalized DPC, varying from 1 to 0 is a useful indicator of the data structure; a value close to 1 indicates no fuzziness in the data whilst a value close to 0 indicates complete fuzziness.

Aside from the above aggregate measures, group average of individual silhouette widths (sw) of members within a group is also computed to indicate the "tightness" of a cluster wherein sw of an individual object $x_{i}$ is defined as:

$$
\begin{aligned}
& s(i)= \begin{cases}1-a_{i} / b_{i} & \text { if } a_{i}<b_{i}, \\
0 & \text { if } a_{i}=b_{i}, \\
b_{i} / a_{i}-1 & \text { if } a_{i}>b_{i} .\end{cases} \\
& \text { or } \quad s(i)=\frac{b_{i}-a_{i}}{\max \left[a_{i}, b_{i}\right]} ; \quad-1 \leq s(i) \leq 1
\end{aligned}
$$

${ }^{4}$ With respect to the present paper, XBI has provided unique solutions, that is, only one minimum value for each analysis. Other measures such as Classification Entropy and Partition Index have also been used but only XBI yields unique solutions for all analyses, that is, XBI provides distinctive numbers of clusters. For other indexes, the results yield rather ambiguous solutions, the highest (or the lowest) value is very close to the second highest (or lowest) value. 
where $a_{i}$ is the average distance between object $x_{i}$ and all other objects in the same cluster and $b_{i}$ denotes the smallest distance between $x_{i}$ and other clusters. A value close to 1 indicates that the object is well-classified, that is, tightly grouped with other members from the same cluster whereas a value near -1 signals high degree of fuzziness. ${ }^{5}$

\section{The ocA Criteria}

The main analytical tool used is ocA theory of which the foundations were laid out by Mundell (1961) and McKinnon (1963) and subsequently refined by Kenen (1969) and Krugman (1990). In essence, as summarized by Artis and Zhang (2002, p. 56) the OCA criteria pertain to real convergence, emphasizing especially as criteria for a monetary union the prevalence of a high degree of intra-trade among the members and the absence of any pronounced asymmetry in the pattern of shocks impacting their economies. This view is echoed by Boreiko (2003, p. 315):

The oca theory concerns about certain benefits and costs associated with adopting a single currency which depend on the degree of convergence of the economies. The benefits are associated with economizing on exchange costs and importing the credibility of the union's central bank, thus reducing the inflationary expectations and level of inflation. As for the associated costs, they are essentially the opposite of the benefits of having an independent monetary policy and exchange rate, which are useful as a means of coping with shocks that are asymmetric between the potential monetary union partners.

Akin to Quah and Crowley (2010), the ocA criteria implemented are openness in trade, business cycle symmetry, inflation convergence, real exchange rate volatility, real interest rate synchronization, export diversification, and labor market flexibility. These dimensions would indicate the level of readiness of every country for fixed exchange rates and cluster analysis would then draw out countries that are symmetrical in their degrees of conformity. This is important such that should a monetary union is formed, intra-union asymmetric shocks can be minimized whilst at the same time pan-union responses to common shocks can be more easily coordinated.

\footnotetext{
${ }^{5}$ Though average sw over all objects can also be used to indicate the appropriate number of clusters, for fuzzy clustering XBI might be more suitable than SW as it incorporates the fuzzy membership coefficients $u_{i k}$ in its formula.
} 
Except for export diversification, the above criteria were implemented earlier using fuzzy cluster analysis by Artis and Zhang (2002) in the European context and interestingly the efficacy of the criteria was proven when Portugal, Italy, Greece, and Spain were accurately distinguished as a group maintaining least conforming ocA features against Germany, which reflects the distressed eurozone members today. ${ }^{6}$

Following the approach employed by Artis and Zhang (2002), the first five dimensions are measured against a reference country while the remaining two dimensions are not measured against any reference. Due to absence of institutional, political, and economic groundwork such as that which exists in the European Union, a monetary anchor would enable East Asia to leap-frog toward a currency area if potential members, including Japan, were willing to entertain the use of a monetary anchor (Mundell, 2003). Besides, the designation of a reference country is also practical for ease of transition and enhanced credibility in the initial stages toward a possible monetary union.

What about the potentiality of a common currency basket anchor? According to McKinnon and Schnabl (2004), there are serious impediments for adopting a common currency basket if major currencies continue to be highly volatile because the basket system would 1) entail complex hedging strategies which might confuse private merchants;2) suggest that authorities maintain sufficient liquidity in not just one but a few major currencies in order to keep their currencies sufficiently close to the target values defined by the common basket; and 3) require picking the appropriate official weights for a common basket for all participant countries which could be extremely problematic.

In light of the above and recent developments in the world economy, the United States, Japan, and China are used as alternative reference countries. The United States is selected as one possible monetary anchor country because of the predominant dollar standard in international trade and capital markets, Japan is chosen because of its significant role in trade and FDI across East Asia, and China is of course one possible reference country since its rise to become one of the largest trading nations and the recent internationalization of its renminbi. ${ }^{7}$

${ }^{6}$ The set of variables used is the most comprehensive hitherto as has been employed in recent publications employing clustering analysis, subject to data availability over countries. The number of dimensions used now is the most comprehensive possible.

${ }^{7}$ Further reasons why United States, Japan and China are selected as prospective anchors can be found in these papers: for the United States, McKinnon and Schnabl (2004), Mundell 
In the first part of analysis symmetrical country groupings relative to each of the reference countries are recognized. In the second part EMU countries are inserted into the cluster analysis so that Asian countries which resemble the eurozone members can be identified. The reference country used for EMU countries is Germany. East Asian groupings which share similar features with the eurozone ones are interpreted as comparatively prepared for monetary union.

For all variables, the data sampled are constrained by data availability but generally range from 1999 to $2009,{ }^{8}$ the period after the Asian turmoil, but include the recent global recession. Since the period examined covers the actual implementation period of unified exchange rates in the EMU, benchmarking against the euro founding countries should be appropriate even if convergence criteria are endogenous (see Frankel and Rose, 1998). Should the ocA criteria be indeed endogenous to eurozone members, Asian countries associated with the EMU members should possess relatively potential attributes for monetary unification. Indeed, as Schiavo (2008) discovered, eurozone has even had more convergence in terms of a number of OCA criteria particularly business cycle synchronicity and trade intensity.

The following subsections discuss the variables. See Appendix for country code and data definitions.

\section{II.1. Openness in Trade (TRA)}

Mundell (1961) and McKinnon (1963) assert that countries which trade a great deal with each other are good candidates for monetary integration as the gains from transaction cost savings and exchange rate certainty

(2007) and Krugman (2009); for Japan, Kawai and Takagi (2005) and Ahn, Kim, and Chang (2006); and for China, Chen and Cheung (2011). For a review on the issue, see Quah (2012c).

${ }^{8}$ The key reason for this time period is to ensure the greatest comparability with the eurozone that introduced the euro in 1999 so that Asian groupings resembling the eurozone ones can be determined. Of course, this is the most recent period that also encompasses the global crisis episode which makes the studied time period more current and relevant. In addition, for less developed East Asian countries, data for the variables labor flexibility and export diversification are only available in very recent years. Also, since the 1997-98 Asian crisis, there have been tighter cross-border monetary and economic cooperations in East Asia such as the land mark 2007 Chiang Mai Initiative and many others. This can be regarded as a "structural change" in policymaking.

For readers interested in an evolutionary view of similar studies that involve the pre 199798 Asian crisis period, see Quah (2012a,b), Quah and Crowley (2010, 2012), and Quah, Crowley, and Ismail (2010). 
would outweigh the potential shock-absorbing capability of flexible exchange rates. Empirically, Bayoumi and Eichengreen (1997) detected that European countries which maintained the greatest levels of bilateral trade also experienced the greatest increase in their readiness for monetary unification. As echoed by Edison and Melvin (1990), in choosing which currency to peg to, a country should emphasize a bilateral trade criterion amongst various other criteria. In the analysis, for a country $i$ trade openness with the reference country (i.e. United States, Japan, or China for East Asia and Germany for eurozone) is measured by bilateral trade intensity, $\left(x_{i, r}+m_{i, r}\right) /\left(x_{i}+m_{i}\right)$ where $x_{i}$ and $m_{i}$ are the exports and imports of goods of the country and subscript $r$ indicates destination to or source from that reference country. Due to data constraints, trade data at annual frequency are used.

\section{II.2. Business Cycle Synchronization (BUS)}

When business cycles are substantially synchronous between two countries, the argument for flexible exchange rates which serve as a shock absorber to resolve asymmetric recessionary or inflationary pressures becomes largely irrelevant. In terms of measurement, it has become popular to implement this OCA criterion according to the synchronicity of business cycles, that is, by evaluating the correlation coefficients of the cyclical component of real output series. In a nutshell, the greater the degree of business cycle synchronicity, the smaller the costs of fixing the exchange rate.

We adopt the method of Baxter and Stockman (1989) where business cycles are identified for each country by applying the Hodrick-Prescott (H-P) filter to series of real GDP, and cross-correlations of the cyclical components vis-à-vis those identified for the reference country then proxy business cycle symmetry. For consistency over countries, annual GDP series at 2005 price level is used to represent real output.

\section{II.3. Inflation Convergence (INF)}

According to Artis and Zhang (2002), the traditional ocA literature originated during the era of "fix-price" economics and hence introducing inflation convergence as a criterion could be regarded simply as an appropriate normalization. From another perspective, Nguyen (2007) argues that since similar inflation rates result from similarities in economic structure and policy stance, the cost of joining a currency area is presumably low 
when inflation rates are similar across members. On top of that, convergence in inflation also reflects similarity in trade union aggressiveness and labor costs between countries, implying less need for flexibility in nominal exchange rates to improve trade imbalances (Fleming, 1971). To an extent, this dimension can be regarded as a measure of cost of joining a monetary union under which the greater the degree of symmetry between countries, the lower the potential costs.

This criterion is measured by the absolute cPI inflation differential, $\left|x_{i}-x_{r}\right|$ where $x_{i}$ and $x_{r}$ are the respective rates of inflation in country $i$ and the reference country. The absolute value is used since the magnitude of the measure is of concern here. Lower differential indicates greater degree of convergence in inflation toward the reference level and vice versa. CPI series used are at monthly frequency.

\section{II.4. Real Exchange Rate Volatility (RER)}

As maintained by Vaubel (1978), the level of a country's need for real exchange rate changes is an important determining factor for joining a monetary union because real exchange rate changes are clearly measurable and automatically give the appropriate weights to the economic forces of which they are the result. These economic forces pertain to inflation rates, openness, economy size, prices, wage flexibility, factor mobility, commodity diversification, goods market integration, and fiscal integration. Accordingly, as Artis and Zhang (1997) put it, low real exchange rate volatility might indicate absence of asymmetric shocks and presence of business cycle conformity that may strengthen the case for a currency area. We represent volatility in the real exchange rate by the standard deviation of the log-difference of monthly real bilateral exchange rates against the reference country, where deflation is accomplished using relative consumer prices. For EMU countries, since nominal exchange rates are unified, variability in real exchange rates boils down to variation in relative consumer prices against Germany. Data series used are at monthly frequency.

\section{II.5. Real Interest Rate Synchronization (INT)}

Though not listed as one of the criteria based on the traditional ocA theory, this factor is indicated by a "revealed preference" argument (Artis and Zhang, 2002). If the monetary policy of a candidate country historically has differed little from that of the reference country, the cost of eschewing 
monetary independence is accordingly low so that synchronization in real interest rates may be interpreted as an indicator of coordination in monetary policy. Also, real interest rate cycle synchronicity with a credible country could imply willingness to commit to policies of high counter-inflationary credibility (Tavlas, 1993). Specifically, we measure this variable by reference to the cross-correlation of the cyclical components of the real interest rate cycle of a country with those of the reference country. The detrending was accomplished by applying the H-P filter to monthly series of real interest rates, defined as the difference between a short-term nominal rate (assumed to be "set" by the Central Bank) and the rate of consumer price inflation. ${ }^{9}$ Data series used are at monthly frequency.

\section{II.6. Diversification in Exports (EXP)}

While McKinnon (1963) stresses the importance of economic openness, Kenen (1969) highlights the relevance of diversification in exports in the choice of exchange rate regime. For a diversified economy, even if each of its export sectors might be subject to adverse shocks, if the shocks are substantially independent and the country produces a sufficiently large variety of different goods, the law of large numbers will come into play and total income will not suffer much. Thus, it is easier to fix the currency value in a diversified economy than that of a specialized economy. Following Nguyen (2007), the degree of export diversification is measured by a diversification index, namely the inverse of the annual Herfindahl index (a popular indicator of the degree of specialization). The Herfindahl index is computed as $H=\sum_{i=1}^{n} s_{i}^{2}$ is where $s_{i}$ is share of the export of product $i$ and $n$ is the number of products exported. The higher the value of this diversification index, the more diversified the exports. Since data of individual export products are unavailable, annual export data according to the firstdigit sub-industries of the United Nation Standard International Trade Classification (SITC) Revision 2 are used. The categories are displayed in table 1.

\footnotetext{
${ }^{9}$ Constrained by data availability, monthly money market rates are used except for China, Belgium, France, and Netherlands where lending rates are used. For Austria, Luxembourg, and Portugal, adequate data are not available and hence their values are replaced by mean over all cases in the analysis.
} 
Table 1. United Nation's Standard International Trade Classification (SITC) Revision 2

\begin{tabular}{cl}
\hline Code & Product type \\
\hline 0 & Food and live animals. \\
1 & Beverages and tobacco. \\
2 & Crude minerals, inedible, except fuels. \\
3 & Mineral fuels, lubricants, and related materials. \\
4 & Animal and vegetable oils, fats and waxes. \\
5 & Chemicals and related products. \\
6 & Manufactured goods classified chiefly by material. \\
7 & Machinery and transport equipment. \\
8 & Miscellaneous manufactured articles. \\
9 & Commodities and transactions not classified elsewhere.
\end{tabular}

Source: Nguyen (2007).

\section{II.7. Labor Market Flexibility (LAB)}

Ingram (1962) and Kenen (1969) argued that domestic labor market flexibility is equally important to transnational labor mobility (popularized by Mundell, 1961) to restore equilibrium in the labor markets amidst asymmetric shocks impacting economic zones within a currency area. In the face of shocks that cannot be easily buffered, internal labor market flexibility is desirable because relatively fast adjustment of employment and real wages could reduce the persistence in unemployment that will otherwise be induced. One measure of rigidity of labor markets that has been used in the literature is a ranking measure of the severity of employment protection legislation (see Artis and Zhang, 2002). In the same vein, due to data

Table 2. Employing workers index definitions

\begin{tabular}{lll}
\hline \multicolumn{1}{c}{ Index } & \multicolumn{1}{c}{ Definition } \\
\hline 1 & Difficulty of hiring & $\begin{array}{l}\text { Difficulty of hiring a new worker. } \\
\text { Restrictions on expanding or contracting the number } \\
\text { of working hours. }\end{array}$ \\
Rigidity of hours & Difficulty of redundancy & $\begin{array}{l}\text { Difficulty and expense of dismissing a redundant } \\
\text { worker. }\end{array}$ \\
4 & Rigidity of employment & Nonwage worker remuneration in percent of salary. \\
\hline
\end{tabular}

Source: Botero, Djankov, La Porta, Lopez-de-Silanes and Schleifer (2003). 
constraints we use the average of the (annual) indexes measuring labor market rigidity by World Bank Doing Business Project to signify labor market flexibility - the smaller the values the greater the levels of flexibility in the labor markets (see table 2 and Botero et al., 2003).

\section{Results}

\section{III.1. Analysis Involving East Asian Countries Only}

First of all, let us look at the Xie-Beni index values to indicate the appropriate number of clusters for the fuzzy cluster analysis. From figure 1, the validation index values suggest four clusters for the solution by the US anchor, three clusters by the Japan anchor, and three clusters by the China anchor. On this finding, the US-based configuration seems to be more fragmented.

Table 3 shows the membership coefficients and the related statistics by the United States, Japan, and China references respectively. Overall, the data partitions are clear-cut with significantly large membership coefficients for belonging to one group only. For aggregate measure, one can look at the average of the largest membership coefficients. In this regard, the Japan-based solution boasts the largest average coefficient at 78.6 per cent. This is corroborated by the highest average silhouette ${ }^{10}$ over all cases at 0.43 and the highest Dunn's coefficient at 0.50 by the Japan reference. By the same measures, the United States partition is less clear and the China partition is the least clear.

The OCA-related features and the silhouettes of the clusters are presented in table 4 . The configurations and the distances between the objects can be visualized using principal component analysis ${ }^{11}$ in figure 2 .

${ }^{10}$ Following Artis and Zhang (2002), in computing the average over all cases, silhouette for single-object cluster is set to zero.

${ }^{11}$ Principal component analysis is a procedure for multivariate analysis which reduces the number of possible correlated variables to a smaller number of uncorrelated variables known as the principal components. Each principal component, PC, is a linear combination of the original variables and may be expressed as $P C_{i}=\alpha_{i 1} X_{1}+\alpha_{i 2} X_{2}+\cdots+\alpha_{i p} X_{p}$, where $i=1,2, \ldots, p$, and $X$ is a data matrix with $n$ observations and $p$ variables. The first principal component is supposed to account for much of the variability in the data, whereas the following principal components explain the remaining variation. For each of the solutions shown here, the first two components explain about 70 per cent of the variations. For the purpose of visualization two components are used and hence the PCA projections do not portray all variations in the data. Because of this and of the "fuzziness" in the cluster memberships amongst the objects, some objects may appear fairly distanced in the projections but are nevertheless belonged to the same grouping. Details on the use of this projection technique can be found in Balasko, Abonyi, and Feil (2004). 
Figure 1. Xie-Beni Index, East Asia
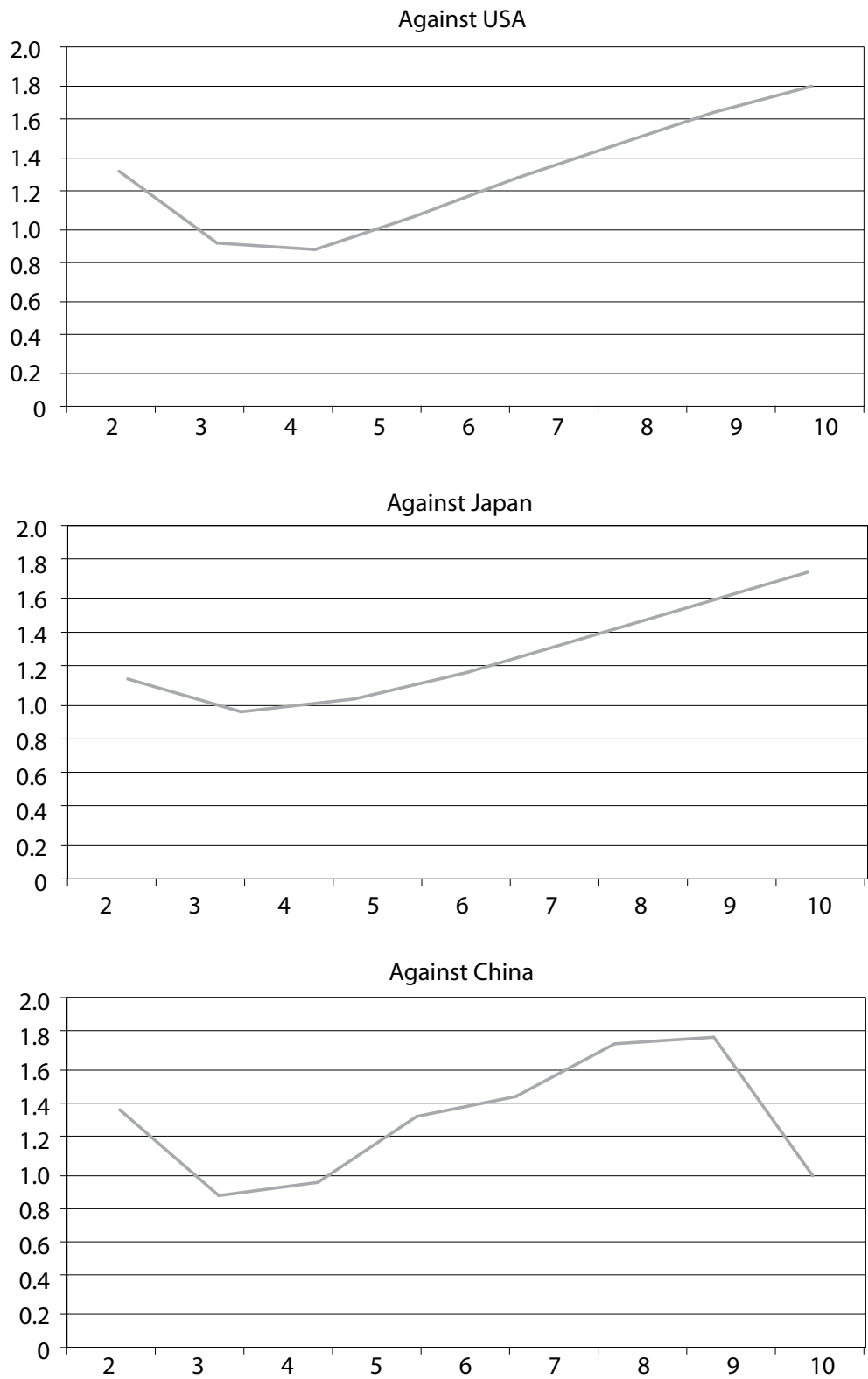

Source: Fuzzy cluster analysis. See Appendix for data description. 


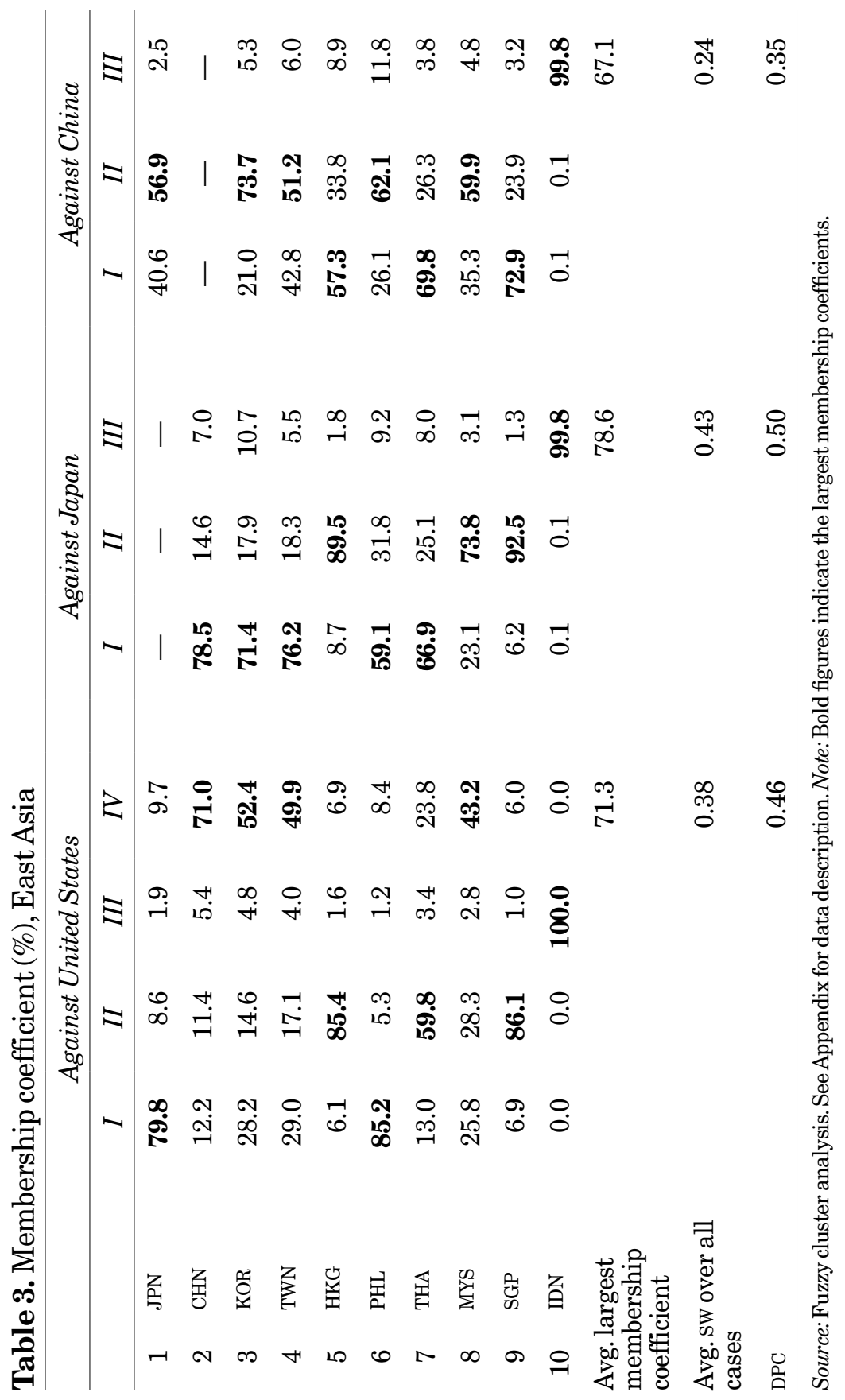


Figure 2. PCA projection
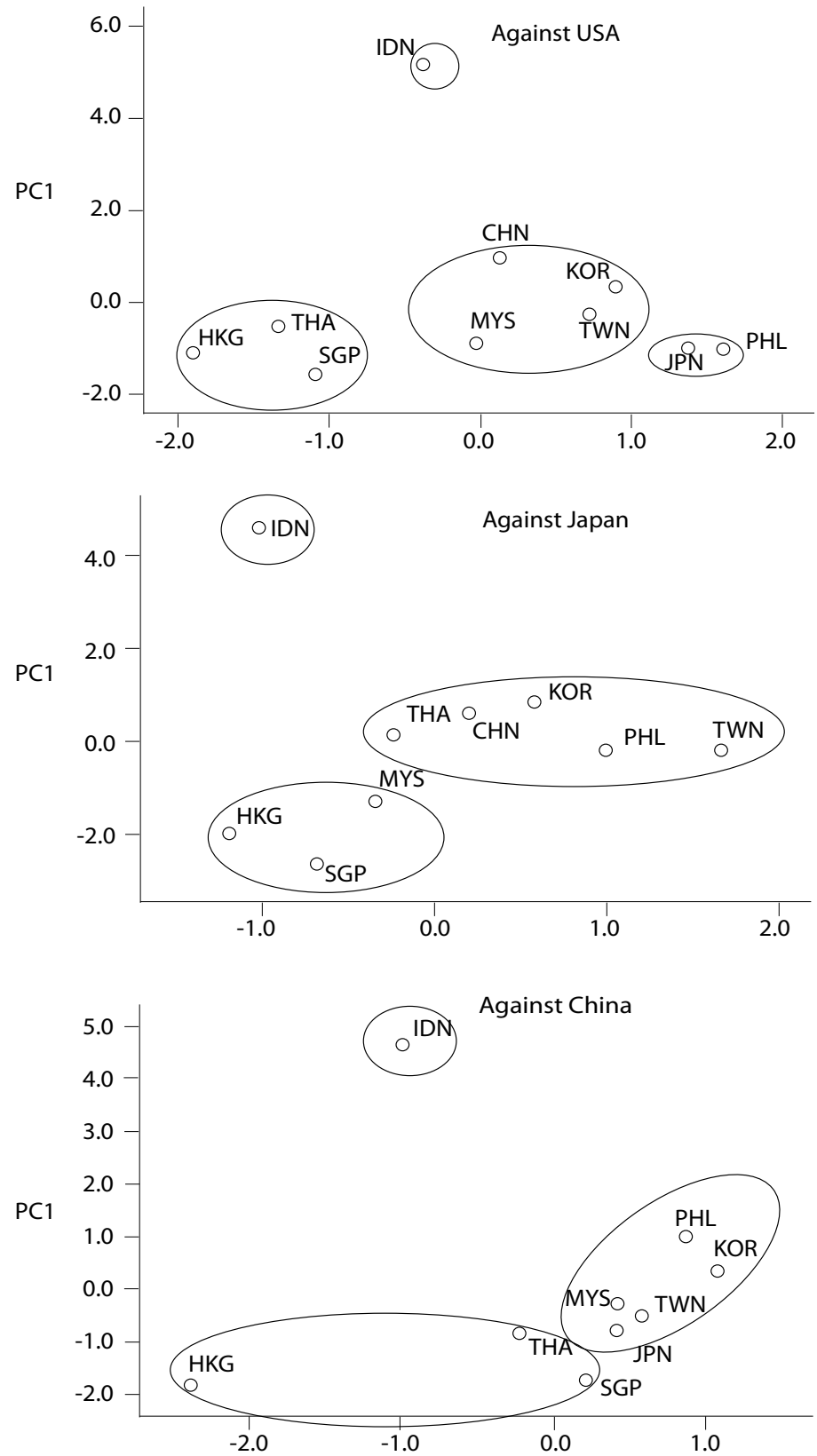

Source: Principal component analysis. See Appendix for data description. 
Table 4. Cluster features, East Asia

\begin{tabular}{ccccccccc}
\hline \multicolumn{10}{c}{ Average } \\
\hline Cluster & SW & TRA & BUS & INF & RER & INT & EXP & LAB \\
& $(\%)$ & & $(\%)$ & & & & \\
\hline
\end{tabular}

Against USA

$\begin{array}{lrrrrrrrr}\quad \text { All Cases } & 0.38 & 14.81 & 0.58 & 2.46 & 2.12 & 0.52 & 3.21 & 20.81 \\ 1 \text { JPN, PHL } & \mathbf{0 . 6 8} & \mathbf{1 9 . 6 8} & 0.79 & 2.79 & 2.49 & 0.58 & 2.06 & 21.44 \\ 2 \text { HKG, THA, SGP } & 0.63 & 12.40 & \mathbf{0 . 8 3} & 2.05 & \mathbf{1 . 4 2} & \mathbf{0 . 6 8} & 3.36 & \mathbf{3 . 6 7} \\ 3 \text { IDN } & 0.00 & 10.38 & -0.04 & 7.17 & 5.05 & 0.13 & \mathbf{5 . 5 2} & 41.50 \\ \begin{array}{l}\text { C CHN, KOR, TWN, } \\ \text { MYS }\end{array} & 0.14 & 15.28 & 0.44 & \mathbf{1 . 4 3} & 1.71 & 0.47 & 3.10 & 28.19\end{array}$

Against Japan

$\begin{array}{lrrrrrrrr}\text { All Cases } & 0.43 & 13.79 & 0.60 & 3.39 & 3.37 & 0.45 & 3.32 & 21.56 \\ \begin{array}{l}\text { CHN, KOR, TWN, } \\ \text { PHL,THA }\end{array} & 0.35 & 15.33 & 0.55 & 2.89 & 3.23 & 0.40 & 3.10 & 28.50 \\ 2 \text { HKG, MYS, SGP } & \mathbf{0 . 6 9} & 9.91 & \mathbf{0 . 8 5} & \mathbf{2 . 0 3} & \mathbf{2 . 8 3} & \mathbf{0 . 6 2} & 2.95 & \mathbf{3 . 3 3} \\ 3 \text { IDN } & 0.00 & \mathbf{1 7 . 7 0} & 0.06 & 9.97 & 5.68 & 0.20 & \mathbf{5 . 5 2} & 41.50\end{array}$

Against China

\begin{tabular}{llllllllr}
$\quad$ All Cases & 0.24 & 13.40 & 0.38 & 2.70 & 2.31 & 0.31 & 3.14 & 19.95 \\
1 HKG, THA, SGP & 0.11 & $\mathbf{1 9 . 8 5}$ & 0.29 & $\mathbf{1 . 6 5}$ & $\mathbf{1 . 5 0}$ & $\mathbf{0 . 5 7}$ & 3.36 & $\mathbf{3 . 6 7}$ \\
$\begin{array}{l}2 \text { JPN, KOR, TWN, } \\
\text { PHL, MYS }\end{array}$ & $\mathbf{0 . 3 6}$ & 10.67 & 0.34 & 2.23 & 2.25 & 0.22 & 2.54 & 25.42 \\
3 IDN & 0.00 & 7.69 & $\mathbf{0 . 8 4}$ & 8.16 & 5.05 & -0.05 & $\mathbf{5 . 5 2}$ & 41.50 \\
\hline
\end{tabular}

Source: Fuzzy cluster analysis. See Appendix for data description. Notes: Bold figures indicate most conforming attributes. *Standard deviation $\left(\mathrm{x} 10^{2}\right)$ of the $\log$ difference in bilateral real exchange rate.

From table 4, immediately one can see that the Japan-based Hong KongMalaysia-Singapore cluster enjoys the greatest group silhouette amongst all clusters of all anchors, signifying the most tightly classified grouping. Their high membership coefficients in table 3 also support this, indicating that they have some common features which are far from being fully shared by other countries. On top of that, the trio is most conforming in virtually all the criteria amongst the Japan-based clusters. ${ }^{12}$ On this evidence, it might

${ }^{12}$ Besides trade relations, another possible factor for high conformity to the dimensions would be FDI and other investments from Japan to these economies since the 1980s, facilitated 
be highly feasible for Hong Kong, Malaysia, and Singapore to jointly fix their exchange rates to the Japanese yen. Nevertheless, this sounds quite ironic given the prevailing dollar standard in Hong Kong. One possible explanation is that besides a dollar peg Hong Kong is also highly feasible for a yen peg. In fact, Hong Kong also exhibits highly conforming features by the United States reference. Hong Kong also shares the same grouping with Singapore in the United States-and China-based arrangements.

In the meantime, it may be persuasive to surmise that countries which are linked with Hong Kong under the United States reference would be comparatively prepared for a rigid dollar peg. Along this argument, Thailand which was severed in the 1997-1998 Asian crisis and Singapore, an international financial hub which had been robust during that period might be comparatively prospective for a dollar standard. Against United States, besides displaying high silhouette they are highly conforming in business cycle symmetry; convergence of inflation; variability in the real dollar rate; synchronization in monetary policy and labor market flexibility. Another cluster exhibiting fairly favorable attributes for dollar peg is the Japan-Philippines duo.

The grouping configuration by China reference is somewhat similar to that by Japan.

Akin to that against the United States, against China the Hong KongThailand-Singapore cluster is once again most conforming in most of the dimensions but showing a much smaller group silhouette, indicating relatively loose linkages between them. The high degree of compliance is not surprising since China, the reference country in this case also pegs to the dollar in practice.

In another respect, it may also be of interest to find that Indonesia is a singleton regardless of anchor country. Distinctively, Indonesia is predominantly characterized by high divergence in inflation, high real exchange rate variability, and low monetary policy synchronicity with any reference country. Different from the rest, it also has the highest degree of business cycle symmetry with China, the most diversified exports, and the most rigid labor market.

To recap, first the US-based arrangement is slightly more fragmented. Second, the Japan reference is associated with clearer data partition than those of the United States and the China reference. Third, Hong Kong,

by the appreciations of yen against the dollar which made investments abroad cheaper for the Japanese. 
Malaysia, and Singapore are shown to closely share highly conforming features for a yen peg. Fourth, Singapore and Thailand which are connected with Hong Kong have exhibited comparatively feasible attributes for a dollar or a yuan peg. Putting the latter two findings together, Singapore and Hong Kong, two international financial hubs today should be relatively potential to form a monetary bloc based on any of the monetary anchors. Fifth, irrespective of reference country Indonesia is always isolated and least compliant in most of the dimensions.

Whilst this exercise addresses the question of cross-country homogeneity, a condition significant for smooth running and sustainability of a possible monetary union, the following analysis classifies the Asian countries together with the founding member states of EMU to determine if any of the Asian economies are parallel to the European countries.

\section{III.2. Analysis Involving East Asian and EMU Countries}

Figure 3 shows the Xie-Beni indexes when EMU cases serving as benchmarks are included into the analysis with the Asian countries. The statistics signify four clusters for the solution by the US anchor, three clusters by the Japan anchor, and three clusters by the China anchor. Table 5 lists the membership coefficients and the associated statistics. Nonetheless, the aggregate statistics are less meaningful in this case as the purpose of the exercise is to identify Asian countries which resemble the euro members. Moreover, different from the Asian countries Germany is the only reference country for EMU cases.

Table 6 shows the cluster findings. Interestingly, the Japan-and China-based configurations each produce a distinctive cluster comprising of 9 EMU countries which maintains a relatively high group silhouette. Except for the labor dimension, ${ }^{13}$ these eurozone states are virtually more conforming to the criteria than the Asian countries, which is consistent with the actual arrangement in the eurozone. Since the time period examined here represents the actual implementation period of euro, this could be in part due to the endogeneity of convergence.

Nonetheless, Ireland is consistently separated by the cluster analysis from other eurozone members and is positioned instead with some Asian countries in all the solutions. But then again, as reflected by the some-

${ }^{13}$ The labor dimension here measures rigidity in the national labor market. Nonetheless, many analysts have maintained that linguistic and cultural barriers have restricted international labor mobility across the eurozone. 
Figure 3. Xie-Beni Index, East Asia plus EMU
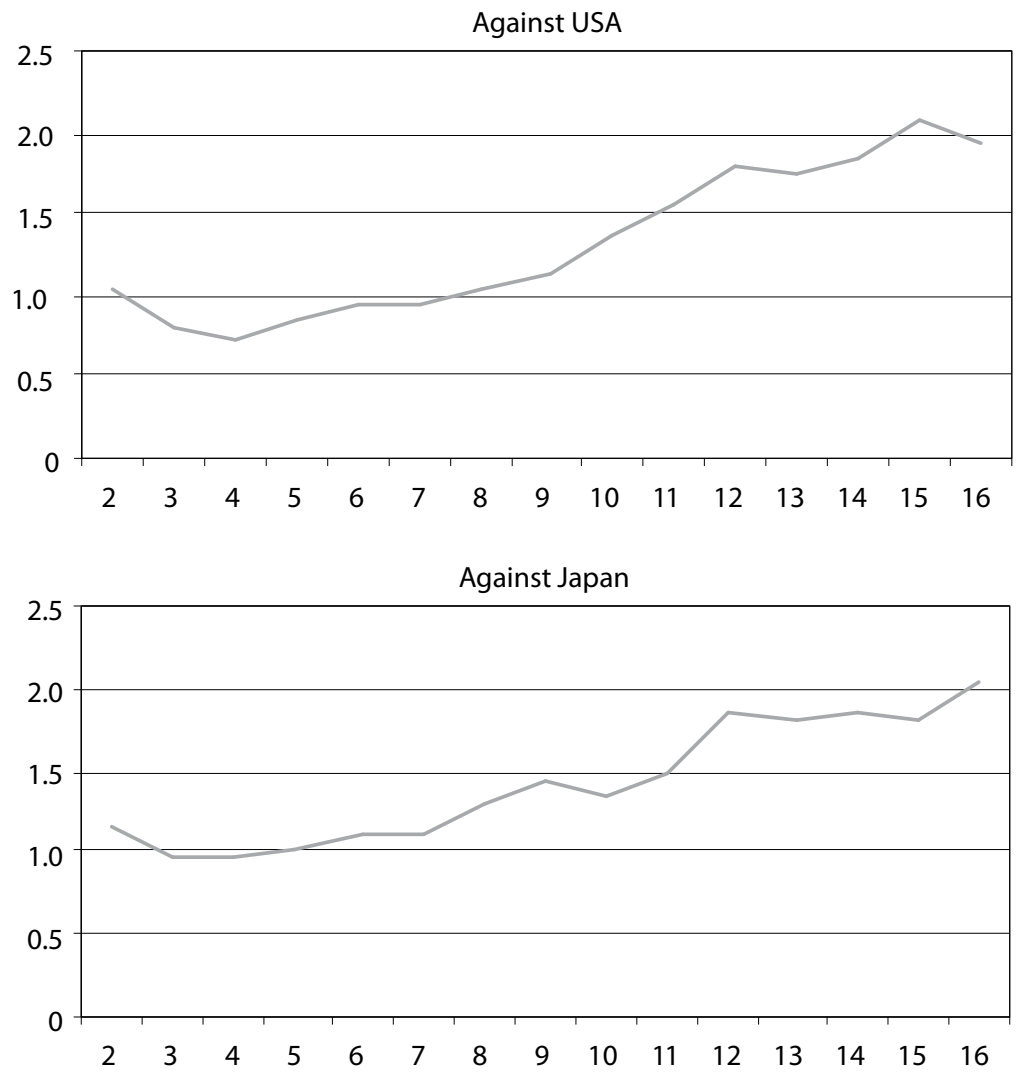

Against China

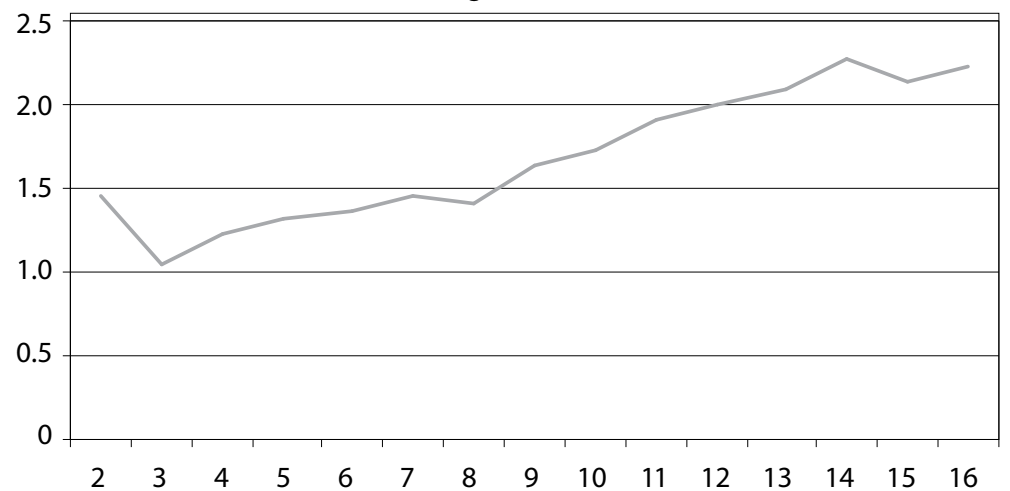

Source: Fuzzy cluster analysis. See Appendix for data description. 


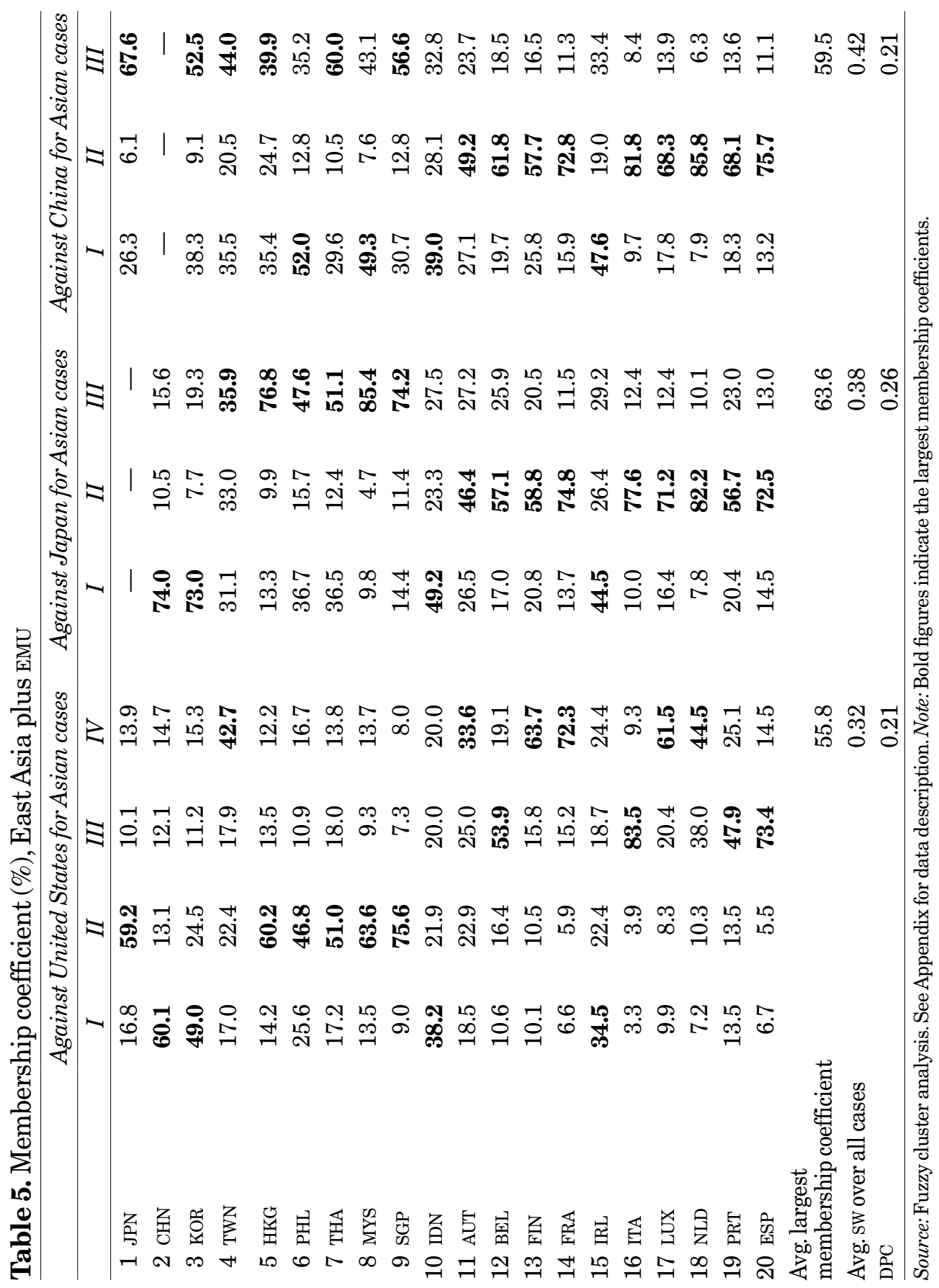


Table 6. Cluster features, East Asia plus EMU

\begin{tabular}{|c|c|c|c|c|c|c|c|c|c|}
\hline \multirow{2}{*}{\multicolumn{2}{|c|}{ Cluster }} & \multicolumn{8}{|c|}{ Average } \\
\hline & & SW & $\begin{array}{l}\text { TRA } \\
(\%)\end{array}$ & BUS & $\begin{array}{l}I N F \\
(\%)\end{array}$ & $R E R^{*}$ & $I N T$ & $E X P$ & $L A B$ \\
\hline \multicolumn{10}{|c|}{ Against USA } \\
\hline & All Cases & 0.32 & 16.01 & 0.67 & 1.72 & 1.29 & 0.44 & 4.06 & 29.44 \\
\hline . & CHN, KOR, IDN, IRL & -0.16 & 12.13 & 0.16 & 3.17 & 2.47 & 0.13 & 4.04 & 27.28 \\
\hline & $\begin{array}{l}\text { JPN, HKG, PHL, THA, } \\
\text { MYS, SGP }\end{array}$ & 0.57 & 15.46 & 0.79 & 2.12 & 1.72 & 0.61 & 2.87 & 10.65 \\
\hline 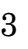 & BEL, ITA, PRT, ESP & 0.56 & 12.74 & 0.80 & 1.07 & 0.43 & 0.68 & 6.01 & 37.75 \\
\hline \multirow[t]{3}{*}{4} & $\begin{array}{l}\text { TWN, AUT, FIN, FRA, } \\
\text { LUX, NLD }\end{array}$ & 0.23 & 21.32 & 0.81 & 0.79 & 0.65 & 0.32 & 3.97 & 44.15 \\
\hline & Against Japan & & & & & & & & \\
\hline & All Cases & 0.38 & 15.59 & 0.68 & 2.12 & 1.84 & 0.40 & 4.16 & 30.25 \\
\hline 1 & CHN, KOR, IDN, IRL & -0.09 & 13.36 & 0.27 & 4.39 & 3.26 & 0.05 & 4.04 & 27.28 \\
\hline 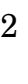 & $\begin{array}{l}\text { AUT, BEL, FIN, FRA, ITA, } \\
\text { LUX, NLD, PRT, ESP }\end{array}$ & 0.48 & 18.21 & 0.81 & 0.82 & 0.46 & 0.46 & 4.99 & 41.17 \\
\hline \multirow[t]{3}{*}{ 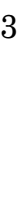 } & $\begin{array}{l}\text { TWN, HKG, PHL, THA, } \\
\text { MYS, SGP }\end{array}$ & 0.55 & 13.16 & 0.78 & 2.56 & 2.97 & 0.55 & 2.99 & 15.85 \\
\hline & Against China & & & & & & & & \\
\hline & All Cases & 0.42 & 15.41 & 0.58 & 1.79 & 1.34 & 0.32 & 4.07 & 29.49 \\
\hline 1 & PHL, MYS, IDN, IRL & -0.13 & 7.49 & 0.62 & 4.66 & 2.79 & 0.03 & 3.48 & 26.75 \\
\hline 2 & $\begin{array}{l}\text { AUT, BEL, FIN, FRA, ITA, } \\
\text { LUX, NLD, PRT, ESP }\end{array}$ & 0.67 & 18.21 & 0.81 & 0.82 & 0.46 & 0.46 & 4.99 & 41.17 \\
\hline 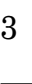 & $\begin{array}{l}\text { JPN, KOR, TWN, HKG, } \\
\text { THA, SGP }\end{array}$ & 0.40 & 16.36 & 0.26 & 1.72 & 2.07 & 0.45 & 2.97 & 16.56 \\
\hline
\end{tabular}

Source: Fuzzy cluster analysis. See Appendix for data description. Notes: Bold figures indicate most conforming attributes. *Standard deviation $\left(\mathrm{x} 10^{2}\right)$ of the log difference in bilateral real exchange rate.

what lower membership coefficients shown by Ireland in its associations with the Asian economies and the corresponding slightly negative silhouettes of the groups in which it is belonged, Ireland is not very closed connected to these Asian countries. This seems to imply that though Ireland is significantly distanced from other eurozone states and is placed closer with the Asian cases, it nevertheless is not "tightly" connected with those Asian countries. Given the different economic structure between East Asia and Western Europe in general and the different reference country assigned to them in this exercise, a linkage which is weak if there is any, between any of the European and the Asian economies is intuitive. 
Specifically, by the United States and the Japan reference, Ireland is placed together with China, Korea and Indonesia. Against China, Ireland is linked with the Philippines, Malaysia and Indonesia. On this finding, these Asian economies should share parallel features with Ireland but since Ireland is one of the eurozone members experiencing financial distress today, instead of being relatively prepared for monetary union these Asian countries may well be as less ready as Ireland.

To check whether this assertion makes sense, one can investigate the ocA-related features of the groupings. Obviously, clusters containing Ireland are commonly characterized by smaller trade linkage, larger inflation divergence, greater real exchange rate variability, and lower synchronization in monetary policy, with each reference country. Along these lines, it is compelling to propose that Asian economies sharing the same grouping with Ireland might be as less feasible a candidate for currency union as Ireland. Therefore, China, Korea and Indonesia might be less suitable for a dollar or a yen standard whilst the Philippines, Malaysia and Indonesia might be less prepared for yuan adoption.

Despite lacking compliance in those criteria Ireland has nevertheless sustained its membership in the EMU till today. One possible reason for this could be the relatively diversified exports and accommodating labor market enjoyed by Ireland that might have alleviated some of the asymmetric experiences with other member states vis-à-vis Germany.

Another cluster containing Asian and EMU countries is the fourth cluster in the US-based solution where Taiwan is merged with five eurozone states, Austria, Finland, France, Luxembourg, and the Netherlands which generally represent the core of EMU. ${ }^{14}$ The desirable features for fixed exchange rates shared by them are high extent of trade intensity, high degree of business cycle symmetry, high inflation convergence, and low exchange rate variability. Nonetheless, they are also characterized by low monetary policy synchronicity, less diversity in exports, and rigid labor market. All in all, Taiwan might be as ready as these EMU countries for unified exchange rates but for Taiwan, the anchor country would be the United States.

In short, using eurozone founding members as a benchmark, depending on the reference country some Asian economies are associated with Ireland and are described by low extent of conformity to the criteria. Quite the opposite, Taiwan is indicated to be somewhat more prepared for monetary unification when the reference country is the United States.

\footnotetext{
${ }^{14}$ See e.g. Artis and Zhang (2002) for references on the discussion of the "core" of EMU.
} 


\section{Discussion and Conclusion}

The paper has implemented fuzzy cluster analysis to draw out homogenous subsets of countries by the OCA-related criteria from the set of East Asian countries with reference to United States, Japan and China, respectively. The same tool is also used to identify Asian economies enjoying attributes parallel to those of EMU founding members in an attempt to infer the level of preparedness for monetary union amongst the Asian economies.

The following observations from the exercise involving the Asian cases only may be noteworthy. First, Japan appears to be a more prospective monetary anchor country of which there have been fewer identified clusters relative to that against the United States reference and of which groupings are more tightly formed in comparison to those of the United States and the China reference. This indicates greater extent of homogeneity vis-à-vis Japan amongst the Asian economies, which might suggest Japan's dominance in the region.

Indeed, this finding corroborates Kawai and Motonishi (2005) and Kawai (2008) who detected that the degree of real economic interdependence with Japan in the emerging East Asia has been greater than that with United States. This is despite the fact that almost the whole region has been on a dollar standard (McKinnon and Schnabl, 2004). But then again, except for Hong Kong the dollar standard across the region has been a "soft" regime rather than a "rigid" one. Hence, it might have been quite feasible for the Asian economies to be more symmetrically associated with Japan but at the same time soft-pegged their currencies to the dollar. Possible facilitating factors for such an arrangement could be the substantial trade surpluses and huge stocks of foreign reserves accumulated by the Asian economies against the United States especially since the Asian turmoil.

Second, Singapore and Hong Kong should be somewhat prospective for a dollar, yen, or yuan bloc. This is so because Hong Kong, Malaysia, and Singapore are found to be symmetrically significant conforming to the OCA criteria against Japan whilst being linked with Hong Kong, Singapore and Thailand have shown highly potential attributes for a dollar or yuan peg. This finding is consistent with the present exchange rate policy of Singapore which pegs its money value to an undisclosed basket of dominant currencies. As for Hong Kong, besides the US dollar it might also be feasible for its currency board to anchor to either the Japanese yen or the 
Chinese renminbi which also pegs to the dollar. Subject to political and social feasibility, and the prospects of globalization of the Chinese yuan as a rival reserve currency to the US dollar and increased trade and financial relations with China, it should be more appropriate and viable for Hong Kong to fix its exchange rate to yuan or even adopt the Chinese renminbi as the currency.

The above finding is comparable to Sato, Zhang and Allen (2009) of which Hong Kong and Singapore were indicated to share long-run comovements of real output with the United States for almost three decades and in Nguyen (2007) Hong Kong and Singapore were signified to have shared similar OCA dimensions in the period after the Asian crisis. Similarly, the supply shocks of Hong Kong and Singapore were detected to be significantly correlated (Ngiam and Yuen, 2001) and their speeds of adjustment to supply disturbances were shown to be faster than those in Western Europe even when the size of disturbances was larger than those in Europe (Bayoumi and Mauro, 2001).

Third, as far as the considerations in this study are concerned, Indonesia which has been significantly idiosyncratic and isolated from the rest irrespective of reference country should be the least prospective candidate for monetary integration.

In the results involving Asian and EMU cases, it is interesting that Taiwan has been grouped with EMU countries which exhibit highly favorable features for monetary union when the United States is the reference country. Another observation is that China, Korea and Indonesia which are put together with Ireland are predominantly described by low conformity to the OCA-related criteria under the United States and the Japan reference. The same is true for the Philippines, Malaysia and Indonesia under the China reference.

In conclusion, the study does not intend to comprehensively assess the feasibility for monetary integration in East Asia since various economic, social, and political factors do come into play. Future scholars may also consider the relative importance to the dimensions examined. For instance, if appropriate, the dimension of output variation (supply shock) symmetry can be given greater emphasis. Nonetheless, the results do at least indicate certain symmetrical subgroups of economies according to some important variables and the relative preparedness for EMU-like integration amongst the economies surveyed.

For that reason, if East Asia were to implement a region-wide monetary union, it should be carried out in stages, that is, the most symmetri- 
cal countries be merged first, and the appropriateness of merging with the rest be evaluated from time to time. Hence, during the transition period toward a single monetary union, exchange rates between the sub-unions will still be flexible, and asymmetric shocks can still be possibly cushioned. Through this successive approach, the likeliness of mismatch between member countries as suffered by euro area whose initial formation included all 11 countries at once can be reduced.

\section{References}

Ahn, C., H-B. Kim and D. Chang (2006), "Is East Asia Fit for an Optimum Currency Area? An Assessment of the Economic Feasibility of a Higher Degree of Monetary Cooperation in East Asia", Developing Economies, 44 (3), pp. 288-305.

Anderberg, M. (1993), Cluster Analysis for Applications, New York, Academic Press.

Artis M. and W. Zhang (1997), "International Business Cycles and the ERM: Is there a European Business Cycle?", International Journal of Finance and Economics, 2 (1), pp. 1-16.

(2002), "Membership of EMU: A Fuzzy Clustering Analysis of Alternative Criteria”, Journal of Economic Integration, 17 (1), pp. 54-79.

Balasko, B., J. Abonyi and B. Feil (2004), Fuzzy Clustering and Data Analysis Toolbox: For Use with Matlab, Hungary, University of Veszprem, retrieved on October 8, 2007, from http://www.mathworks.com/matlabcentral/fileexchange/loadFile.do?-objectId $=7486$.

Baxter, M. and A. C. Stockman (1989), "Business Cycles and the Exchangerate Regime”, Journal of Monetary Economics, 23 (3), pp. 377-400.

Bayoumi, T. and P. Mauro (2001), "The Suitability of ASEAN for a Regional Currency Arrangement”, The World Economy, 24 (7), pp. 933-954.

Bayoumi, T. and B. Eichengreen (1994), "One Money or Many? Analyzing the Prospects for Monetary Unification in Various Parts of the World", Princeton Studies in International Finance, 76, Princeton, International Finance Section, Princeton University.

Bayoumi, T. and B. Eichengreen (1997), "Ever Closer to Heaven? An Optimum-currency-area Index for European Countries”, European Economic Review, 41 (3-5), pp. 761-770.

Bezdek, J. C. (1973), Fuzzy Mathematics in Pattern Classification, Nueva York, Cornell University.

Boreiko, D. (2003), "EMU and Accession Countries: Fuzzy Cluster Analysis 
of Membership", International Journal of Finance and Economics, 8 (4), pp. 309-325.

Botero, J., S. Djankov, R. La Porta, F. Lopez-de-Silanes and A. Schleifer (2003), “The Regulation of Labor", Quarterly Journal of Economics, 119 (4), pp. 1339-1382.

Chen, X. and Y.-W. Cheung (2011), "Renminbi Going Global”, China \& World Economy, 19 (2), pp. 1-18, doi: 10.1111/j.1749-124X.2011.01232.x. Choi, Yun Jeong, Doyeon Kim and Taeyoon Sung (2010), "Global Crisis, Exchange Rate Response, and Economic Performance: A Story of Two Countries in East Asia", Global Economic Review, 39 (1), pp. 25-42.

Crowley, P. M. (2004), "A Single Currency for NAFTA?", Research in Global Strategic Management, 10, pp. 153-173, retrieved on June 15, 2008, from ScienceDirect database.

Dunn, J. C. (1973), "A Fuzzy Relative of the Isodata Process and its Use in Detecting Compact, Well-separated Clusters", Journal of Cybernetics, 3 (3), pp. 32-57.

Edison, H. and M. Melvin (1990), "The Determinants and Implications of the Choice of an Exchange Rate Regime", in W. S. Haraf and T. D. Willett (eds.), Monetary Policy for a Volatile Global Economy, Washington, AEI Press.

Fleming, J. M. (1971), “On Exchange Rate Unification”, Economic Journal, 81, pp. 467-488.

Frankel, J. and A. Rose (1998), "The Endogeneity of the Optimum Currency Area Criteria", Economic Journal, 108 (449), pp. 1009-1025.

Goto, J. and K. Hamada (1994), "Economic Preconditions for Asian Regional Integration”, in T. Ito and A. O. Krueger (eds.), Macroeconomic Linkage: Savings, Exchange Rates and Capital Flows, Chicago, University of Chicago Press, pp. 359-385.

Ingram, J. (1962), Regional Payments Mechanisms: The Case of Puerto Rico, Chapel Hill, University of North Carolina Press.

Kaufman, L. and P. Rousseeuw (1990), Finding Groups in Data: An Introduction to Cluster Analysis, New York, Wiley.

Kawai, M. (2008), "Toward a Regional Exchange Rate Regime in East Asia”, Pacific Economic Review, 13 (1), pp. 83-103, retrieved on August 12, 2008, from Synergy Blackwell database.

Kawai, M. and T. Motonishi (2005), "Macroeconomic Interdependence in East Asia: Empirical Evidence and Issues", in Asian Economic Cooperation and Integration Progress, Prospects and Issues, Manila, Asian Development Bank. 
Kawai, M. and S. Takagi (2005), "Strategy for a Regional Exchange Rate Arrangement in East Asia: Analysis, Review, and Proposal”, Global Economic Review, 34 (1), pp. 22-65.

Kenen, P. (1969), "A Theory of Optimum Currency Areas: An Eclectic View", in R.A. Mundell and A. K. Swoboda (eds.), Monetary Problems of the International Economy, Chicago, University of Chicago Press.

Krugman, P. (1990), "Policy Problems of a Monetary Union", in P. de Grauwe and L. Papademos (eds.), The European Monetary System in the 1990s, Harlow, Longman.

Krugman, P. R. (2009), “China's Dollar Trap”, retrieved on April 6, 2008, from http://www.nytimes.com/-2009/04/03/opinion/03krugman.html?_r=1.

McKinnon, R. (1963), "Optimum Currency Areas", American Economic Review, 53 (4), pp. 717-725.

McKinnon, R. I. and G. Schnabl (2004), “The Return to Soft Dollar Pegging in East Asia: Mitigating Conflicted Virtue", International Finance, 7 (2), pp. 169-201.

Mundell, R. (1961), "A Theory of Optimum Currency Areas", American Economic Review, 51 (4), pp. 657-664.

(2003), "Prospects for an Asian Currency Area", Journal of Asian Economics, 14 (1), pp. 1-10.

(2007), "Dollar Standards in the Dollar Era", Journal of Policy Modeling, 29 (5), pp. 677-690.

Ngiam, K. J. and H. Yuen (2001), "Monetary Cooperation in East Asia: A way Forward", The Singapore Economic Review, 46 (2), pp. 211-246.

Nguyen, T. (2007), "East Asian Currency Area: A Fuzzy Clustering Analysis of Homogeneity", Development and Policies Research Center Working Paper no. 10, DPRC, Vietnam.

Quah, C. H. (2012a), "Is East Asia as Prepared as Eurozone for Monetary Union?", Journal of Business, Economics and Management, 13 (3), pp. 471-488.

(2012b), "Can Japan or China Replace the US as the Monetary Anchor for Hong Kong and Macau?", Asia Pacific Business Review, 18 (3), pp. 335-354.

(2012c), "The Case for Monetary Union in East Asia: From Theory to Empirics", in Business Management, Rijeka, Croatia, InTech Open Access Publisher.

Quah, C. H. and P. M. Crowley (2012), "Which Country should be the Monetary Anchor for East Asia: The US, Japan or China?", Journal of the Asia Pacific Economy, 17 (1), pp. 94-112 
Quah, C. H., P. M. Crowley and M. N. Ismail (2010), "Monetary Anchor for East Asia: Japan or United States?”, African Journal of Business Management, 4 (6), pp. 1048-1058.

Quah, C. H. and P. M. Crowley (2010), "Monetary Integration in East Asia: A Hierarchical Clustering Approach”, International Finance, 13 (2), pp. 283-309.

Sato, K., Zhang, Z. y D. Allen (2009), "The Suitability of a Monetary Union in East Asia: What does the Cointegration Approach Tell?", Mathematics and Computers in Simulation, 79 (9), pp. 2927-2937.

Schiavo, S. (2008), "Financial Integration, Gdp Correlation and The Endogeneity Of Optimum Currency Areas", Economica, 75 (297), pp. 168189. Doi: 10.1111/J.1468-0335.2007.00598.X

Tavlas, G. (1993), "The 'New' Theory of Optimum Currency Areas", The World Economy, 16 (6), pp. 663-685.

Tsangarides, C. and M. S. Qureshi (2008), "Monetary Union Membership in West Africa: A Cluster Analysis", World Development, 36 (7), pp. 1261-1279, retrieved on May 08, 2008, from ScienceDirect database.

Vaubel, R. (1978), Strategies for Currency Unification, Tubingen, J. C. B. Mohr.

Wilson, P. and K. M. Choy (2007), "Prospects for enhanced Exchange Rate Cooperation in East Asia: Some Preliminary Findings from Generalized PpP Theory", Applied Economics, 39 (8), pp. 981-995, retrieved on September 9, 2008, from Informaworld database.

Witte, M. D. (2010), "Asian Exchange Rates during the Credit Crisis: Policies to Avoid Depreciation", Global Economic Review, 39 (1), pp. 15-24.

Xie, X. and G. Beni (1991), "A Validity Measure for Fuzzy Clustering”, IEEE Transactions on Pattern Analysis and Machine Intelligence (PAMI), 13 (8), pp. 841-847. 


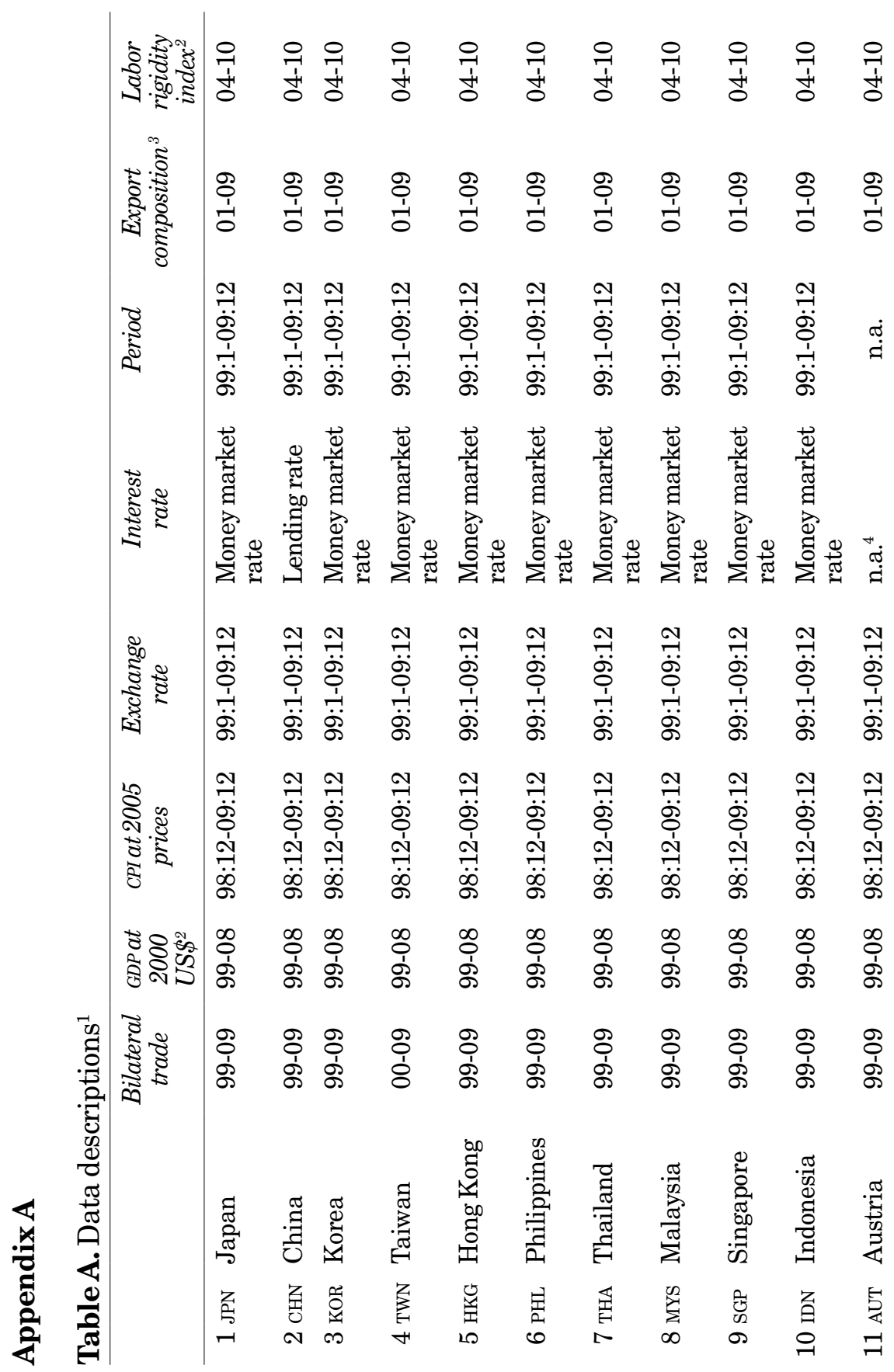




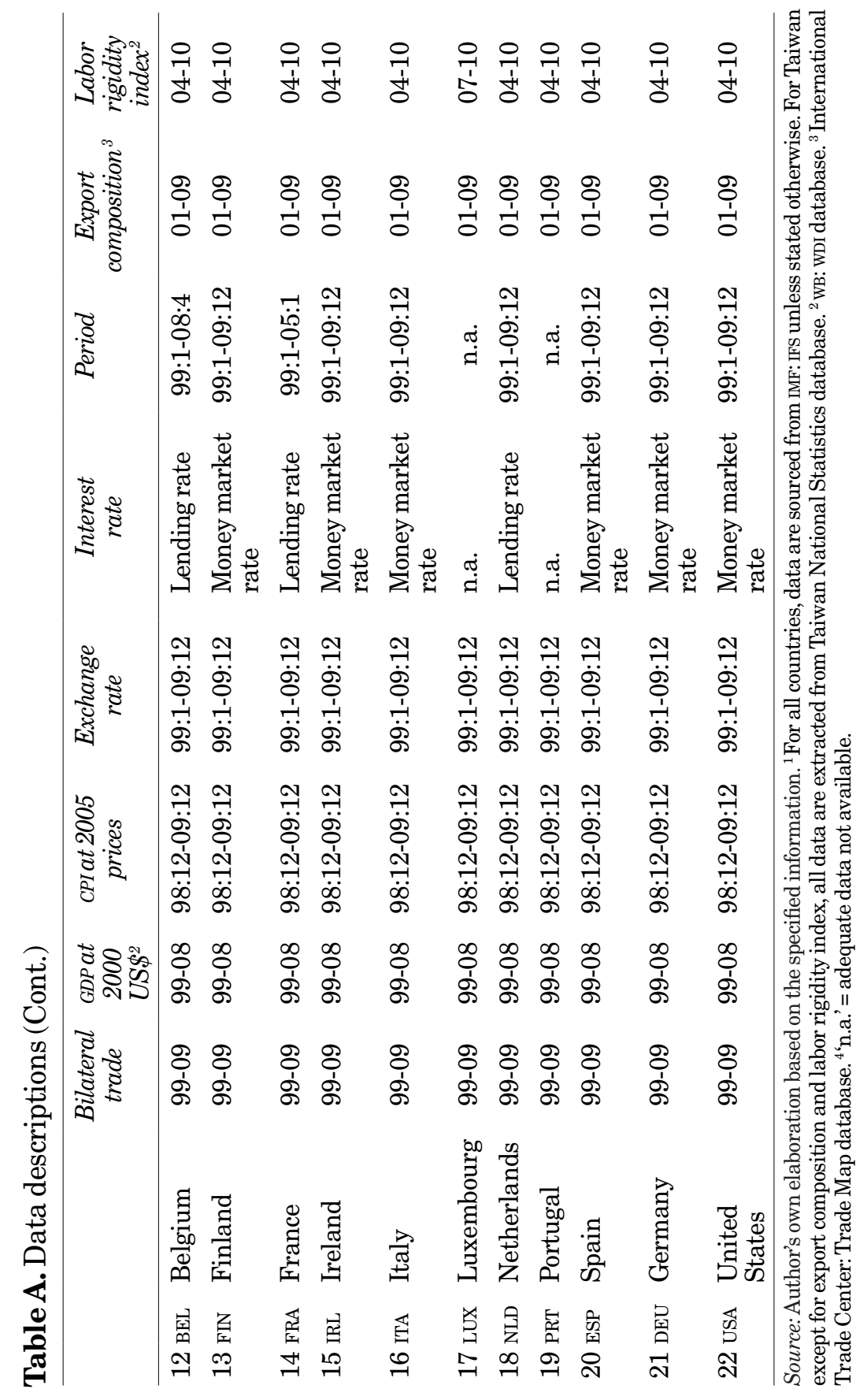




\section{Appendix B}

Firstly, cluster analysis is capable of drawing out homogeneous groupings of countries given a set of criteria - a feature not offered by cointegration approach, VAR analysis, or OCA index.

Secondly, time-series modeling techniques by and large only examine a very limited number of dimensions at a time, such as symmetry in real exchange rate movements and/or symmetry in responses to shocks, assuming that these dimensions also reflect other facets of convergence. Nevertheless, while these dimensions are important, they do not necessarily represent other important facets. In this aspect, cluster analysis has obvious advantages as it can take into consideration multiple relevant dimensions simultaneously and gives equal importance to each dimension.

The main reason for the above could also lie in the fit between the methods and the characteristics of the variables or data. Modeling techniques generally require data to be time-series, stationary at least after transformation, of certain variability, and satisfy specific distributional assumptions. Even if a least-rigorous modeling technique is used, the available data are most likely insufficient to analyze a relatively short time period. Quite the reverse, cluster analysis is compatible with investigation of short time periods with few data points; a crucial feature when dealing with less developed Asian countries with limited dataset.

Thirdly, as Crowley (2004) pointed out, the SVAR approach has been criticized for being arbitrary in terms of restrictions required for identification of monetary and real shocks. Cluster analysis, on the other hand, does not face this problem.

Lastly, besides providing partitioning for the countries, fuzzy cluster analysis could assign each country a degree for belongingness to every cluster.

Source: Author's own elaboration. 